\title{
The SUPREME Court Restates DIRECTORS' FiduCIARY DUTY - A COMMENT ON PEOPLES DEPARTMENT STORES V. WISE
}

\author{
DARCY L. MACPHERSON
}

This article considers the implications of the recent Supreme Courl of Canada decision in Peoples Department Stores v. Wise for the law of directors' fiduciary duttes. The Court's decision is attacked on noo grounds.

First, the author criticizes the Court's interpretation and treatment of the phrase "the best interests of the corporation" as found in the Canada Business Corporations Act $h$ is argued that the decision in Wise rejects the traditional interpretation of this phrase which was previously accepted to mean "the best interests of the shareholders collectively." This rejection raises the spectre of the debate between the "shareholder primacy" model of directors' duties and broader "pluralist" alternatives. By undercutting the lynchpin of the "shareholder primacy" model, the author suggests that the Court has left a vacuum in the law because the Court failed to oulline what is to replace this traditional interpretation. or even to acknowledge the substantive change being made. At the level of process, it is equally suggested that the revision of important principles in corporate law exclusively through the judictary is fiundamemally undesirable, where the law of directors' duties has such a large element of public policy attached to it. The author also proposes that the decision in Wise has resulted in an unacceplable level of uncertainty in the low, and that this uncertainty was neither necessary nor advisable to resolve the case before the Court.

Second, the author criticizes the Court 's comments indicating that a breach of fiduciary duty requires mala fides on the part of directors. It is argued that this is inconsistent with pre-existing case law:
Cet article portc sur les implications de la récente décision de la Cour suprème du Canada. à savoir Peoples Department Stores c. Wise relativement ast droir du devoir fiduciel des administrateurs. La décision de la Cour a été atlaquée sur deux molifs. Premièrement. l'auteur critique l'interprétation de la Cour de la phrase "le meilleur intérèt de la société " conformément à la Loi canadienne sur les sociétés par action. On prétend que la décision dans I'affaire Wise rejette l'interprétation traditionnelle de celte phrase qui avait, auparavant. été acceptée dans le sens de " meilleur intérèt des actionnaires collectivement ". Ce rejel soulève le spectre d'un débat entre les droits des administrateurs selon le modele de la " primaunes des acrionnaires "et les approches * pluralistes " plus larges. En affaiblissant le pilier du modele de la "primaute des actionnaires ". l'auteur laisse entendre que la Cour laisse un vide dans le droir parce qu'elle n'a pas dit par quoi l'interpreitation Iraditionnelle eitait remplacée, ni d'ailleurs a-i-elle confirmie qu un changemem avait été fait. Quumt au processus, on suggère cuussi que le fail que la révision de principes imporiants dans le droit des sociétés soil effectue uniguement par la magistrature est tout à fail indisirable. d'autant plus que les obligations des administrateurs comporte un élément de politigue publique considérable. L'auttur suggère que la décision Wise ait donné lieu à un degré d'incertitude inacceptable dans le droit et que cette incertitude ne füt ni nécessaire ni conseillée pour régler lé cas devant la Cour.

Puis, l'auteur critique les commentaires de la Cour à leffet que pour violer le devoir fiduciel. les adminisirateurs doivent fairc preave de manvalse for. On prisend que cela est incompatible avec la jurisprudence aciuclle.

\section{TABLE OF CONTENTS}

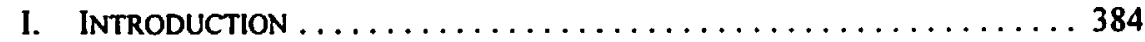

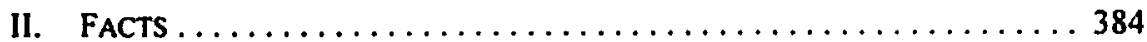

III. Conclusions $\ldots \ldots \ldots \ldots \ldots \ldots \ldots \ldots \ldots \ldots \ldots \ldots \ldots \ldots \ldots \ldots, 386$

Assistant Professor, Faculty of Law, University of Manitoba. Generous financial support was received from the Legal Research Institute. University of Manitoba. The research support of Doug Schweitzer is also gratefully acknowledged. 

A. WhAT DoEs "THE BEST INTERESTS OF THE
Corporation" MEAN? ..................... 386
B. MALA FIDES AND FIDUCIARY DUTY ............... 388

IV. WHAT DOES "THE BEST INTERESTS OF THE

Corporation" MEAn? . ........................ 388

A. FOR WHOSE BENEFIT IS THE CORPORATION

TO BE RUN? . . . . . . . . . . . . . . . . . . . . . . . . 388

B. Process Concerns $\ldots \ldots \ldots \ldots \ldots \ldots \ldots \ldots \ldots \ldots \ldots \ldots \ldots$

C. UnCERTAINTY CONCERNS $\ldots \ldots \ldots \ldots \ldots \ldots \ldots \ldots \ldots, \ldots, \ldots \ldots \ldots$

V. MALA FIDES AND FIDUCIARY DUTY $\ldots \ldots \ldots \ldots \ldots \ldots \ldots \ldots, \ldots 4 \ldots \ldots \ldots$

VI. WHAT IS NEXT? .......................... 405

\section{INTRODUCTION}

In light of the decision of the Supreme Court of Canada in Peoples Department Stores $v$. Wise, the Canadian corporate bar is confronted with a number of issues. These include: (i) the proper interpretation of the statutory duty of care under s. 122(1)(b) of the Canada Business Corporations $A c t{ }^{2}$ (ii) the impact of what is now s. 123(5) of the $C B C A$; and (iii) the impact of repealing the $C B C A$ 's former prohibition on financial assistance. Despite these issues the author has, in this comment, decided to focus on the issue of the statutory statement of fiduciary duty contained in s. 122(1)(a) of the $C B C A$. This is not to suggest that these other issues are unimportant. In $f^{-} t$, quite the opposite is true. The changes to the statutory duty of care are especially significant. But these are important enough to warrant more extensive discussion than space allows here. Therefore, this discussion will have to wait for another day.

As for the issues to be addressed in this comment, the Court's decision in Wise has, on the face of it, altered the meaning of the term "the best interests of the corporation," as used in the $C B C A$. There are three relevant aspects to the change that will be highlighted here: (i) for whose benefit is the corporation to be run? This raises the spectre of a debate between the "enlightened shareholder value" approach to management, as against the "pluralist" approach; (ii) regardless of the relative merits of the approaches, changing the "enlightened shareholder value" approach by Supreme Court edict raises serious process concerns; and (iii) the change creates uncertainty in the law. This change was not necessary to allow the Court to reach the result it did on the facts of the case before it, nor was the change advisable given the guidance - or, more appropriately, the lack thereof — provided by the Court in its judgment.

\section{FACTS}

Before tuming to these issues, it is necessary to appreciate the factual background of the case itself. In Wise, the individual respondents (the Wise brothers) were directors of Wise Stores Inc. ${ }^{3}$ In 1992, Wise Stores Inc. acquired Peoples Department Stores Inc. (Peoples) 
from Marks \& Spencer Canada Inc. ${ }^{4}$ Due to the way that the deal was structured, a specific prohibition was placed in the agreement to prevent Wise Stores Inc. from amalgamating with Peoples. ${ }^{5}$ Later, Peoples became the wholly-owned subsidiary of Wise Stores Inc., and the Wise brothers were the sole directors of Peoples. ${ }^{6}$ Unfortunately, the attempted streamlining of the operations of the two companies that took place thereafter did not go well. There were terrible problems in attempting to streamline acquisitions, warehousing and bookkeeping.' The eldest Wise brother asked the vice-president of administration and finance, one Clement, to develop a new system to cure these difficulties.

At Clément's recommendation, the Wise brothers implemented a new inventory procurement policy. Under it, Peoples would make all purchases within North America for both corporations, and invoice Wise for the inventory Wise used. The inverse was true of purchases made elsewhere - that is, Wise would purchase the inventory and invoice Peoples. ${ }^{9}$ Since the vast majority of inventory was purchased in North America, this meant that Wise would owe a good deal of money to Peoples. ${ }^{10}$ Although there was originally no complaint from representatives of Marks \& Spencer Canada Inc., upon realizing the degree of the inter-company loan, Marks \& Spencer Canada Inc. demanded (and received) further concessions from Wise." Despite the attempt to save the two corporations, the two were forced into bankruptcy as of 9 December 1994, approximately ten months after the new policy was implemented. ${ }^{12}$ The trustee in bankruptcy then sued the Wise brothers, claiming that the implementation of the new procurement policy violated the statutory fiduciary duty and the statutory duty of care - both pursuant to s. 122(1) of the CBCA. In addition, the trustee claimed that the Wise brothers were liable under 5. 100 of the Bankrupicy and Insolvency $A c t .{ }^{13}$ In this comment, attention will focus on the discussion of duties under the $C B C A$. Issues arising from the $B I A$ will not be addressed.

One other issue should be canvassed before turning to the legal analysis. At the beginning of the judgment, Major and Deschamps JJ., for the Court, held: "In our view, it has not been established that the directors of Peoples violated either the fiduciary duty or the duty of care imposed by s. 122(1) of the CBCA."14 This comment should not be seen as challenging the end result of the case. It may well be that the Wise brothers did not breach any duties placed on them by statute. Instead, the crux of this comment lies in the law which, according to the Court, drives them to this result. Therefore, it is this reasoning to which attention should now turn.

Ibid. at para. 8.

Ibid. at para. 11.

Ibid. at para. 12

lbid. at paras. 13-16.

lbid. at para. 17.

lbid.

/bid. at para. 18.

Ibid. at paras. 19-20.

lbid. at para. 23.

R.S.C. 1985 , c. B-3 $[B \mid A]$.

Wise, supra note I at para. 3 


\section{Conclusions}

Given the length of what follows, it will be helpful to lay out at the beginning the conclusions to be drawn from the analysis. Therefore, in point form, the analysis runs thus:

\section{A. What Does "The Best Interests of the CoRporation" Mean?}

\section{FOR WHOSE BENEFIT IS THE CORPORATION TO BE RUN?}

Directors owe a statutory fiduciary duty to protect the best interests of the corporation;

Traditionally, despite the occasional judicial statement of a broader view, the weight of authority has held that the "best interests of the corporation" were to be equated with the best interests of the shareholders collectively;

- The Court in Wise rejected this traditional idea. However, the case law cited by the Court for this proposition in Canada - namely, Teck Corp. Ltd. v. Millar ${ }^{15}-$ arguably does not support this rejection;

- The Court does not explain what is supposed to replace the traditional notion, except that the directors are "not to favour the interests of any one group of stakeholders 116 and instead, they are to consider all relevant constituencies;

This represents a substantial change to the law, both in the United Kingdom - from where Canada received most of its early precedents on this topic, and whose law is still very influential — and Canada;

The U.K. has already examined the issues around directors' duties;

This examination in the U.K. showed that there were two basic approaches to directors' duties: (a) "enlightened shareholder value," on the one hand; and (b) "pluralist" approaches, on the other;

This examination in the U.K. recommended that the "enlightened shareholder value" approach be retained in the U.K., provided that the approach was defined in an inclusive way;

The Supreme Court of Canada in Wise does not seem to recognize that the concept of "enlightened shareholder value" does not foreclose the consideration of the impact of the decisions of directors on the other constituencies referred to; 


\section{PROCESS CONCERNS}

- Even if the substantive result of the U.K. experience - that is, the choice of the "enlightened shareholder value" approach over its pluralist competitor - could be questioned, the integrity of the process by which that decision was reached is virtually unassailable. The U.K. process was a public, consultative process undertaken at the behest of the government. This is in sharp contrast to the process adopted by Supreme Court of Canada in Wise;

- The Court's decision is based on the submissions of private parties. However, certain fundamental areas of corporate law, such as directors' duties, have an important public-policy component to them, which should be explicitly considered;

The Court's decision was neither public nor consultative, nor can it be so;

The Court did not undertake this review of directors' duties at the request of the government;

There are examples of consultative processes undertaken by legislators and regulators when considering fundamental changes to the regulatory environment in which businesses operate. These examples demonstrate the importance of the involvement of business interests in making changes to laws that affect those interests;

- Interestingly, many of these process points were raised by the Quebec Court of Appeal as a reason to overturn the trial court's decision. Notwithstanding that the Supreme Court of Canada affirmed the Court of Appeal, the Supreme Court's decision is vulnerable to the same argument made by the Court of Appeal in response to the trial judgment;

\section{UNCERTAINTY CONCERNS}

- The trustee of Peoples argued that the fiduciary duty ought to shift to protect creditors when the corporation is "in the vicinity of insolvency";

- The Supreme Court of Canada disagreed, based in part on the uncertainty of the term "in the vicinity of insolvency";

- However, the solution proposed by the Court is actually more uncertain than the request of the trustee that was rejected earlier;

- Ultimately, the Court did not need to give an expansive answer on the nature of directors' duties in order to resolve the narrow issue before it. Given this, it is curious that the Court voluntarily took the task upon itsclf;

Finally, the decision of the Court provides no guidance as to how this new view of fiduciary duty is to be applied in future cases: 


\section{B. MALA FIDES AND FidUCIARY DUTY}

- In one part of its judgment, the Supreme Court says the lack of mala fides and personal benefit by the directors undermines a claim for breach of fiduciary duty;

- On the particular facts of Wise, this may be sufficient to resolve the case;

However, as a general rule, case law indicates that there can still be a breach of fiduciary duty, notwithstanding that there is a lack of both mala fides and personal benefit to the directors.

Having laid out the conclusions to be drawn, let us now turn to the analysis through which these conclusions are justified.

\section{WHAT DOES "THE BEST INTERESTS OF THE CORPORATION" MEAN?}

\section{A. FOR WhOSE BENEFIT IS THE CORPORATION TO BE RUN?}

Section 122(1)(a) of the CBCA sets out the statutory formulation of fiduciary duty as follows:

122(1) Every director and officer of a corporation in exercising their powers and discharging their duties shall (a) act honesily and in good faith with a view to the best interests of the corporation ... ${ }^{17}$

In Wise, in accordance with established precedent, ${ }^{18}$ the fiduciary duty was held to be owed to the corporation. ${ }^{19} \mathrm{~W}$ ith that, there should be no quarrel..$^{20}$ Prior to this case, it had long been thought that the "best interests of the corporation" meant the best interests of all of the shareholders collectively." As it was put in Westfair Foods Lid. v. Watt:

The phrase "best interests of the corporation" has been judicially interpreted to mean the best interests of the sharcholders taken as [a] wholc: Greenhalgh v. Arderne Cinemas LAd. [1951] Ch. 286, [1950] 2 All E.R. 1120 (C.A.): Palmer v. Carling O Keefe Breweries of Can. Lid. (1989), 67 O.R. (2d) 16I, 4I B.L.R. 128, D.I.R.

I* See, for example, Aberdeen Railway Co. v. Blaikje Bros. [1843-60] All E.R. 249 (H.L.) [Aberdeen] UPM-Kymmene Corp. v. UPM-Kymmene Miramichi (2002), 214 D.L.R. (4th) 496 (Ont. Sup. C.); aff d (2004), 250 D.L.R. (4th) $\$ 26$ (C.A.).

1.) Wise, supra note $I$ at para. 41 .

23. See, for example, A. Douglas Harris et al. Cases. Materials and Notes on Partncrships and Canadian Business Corporations, 4th ed. (Toronto: Thomson Carswell, 2004) at 376. Here the authors point out that one of the ways to vindicate a fiduciary breach is through a derivative action by a shareholder. In a derivative action, a shareholder asserts the rights of the corporation. See $C B C A$, supra note $2,5.239$. This must mean that a fiduciary duty is owed to the corporation. See also Bruce Welling et al. Canadian Corporate Law: Cases, Notes \& Materials, $2 \mathrm{~d}$ ed. (Markham, Ont: Butterworths Canada, 2001 ) at 284-85, as well as J. Anthony VanDuzer, The Law of Partnerships and Corporations, $2 \mathrm{ded}$. (Toronto: Irwin Law, 2003) at 269.

: See 820099 Ontario v. Harold E. Ballard Lid. (1991), 3 B.L.R. (2d) 123 at 182 (Ont. Cl. Gen. Div.), aff d (1991), 3 B.L.R. (2d) 113 (Ont. Div. Ct.) [820099]. 
(4th) 128, 32 O.A.C. 113 (Div. Ct.): Howard Smith Lid. v. Ampol Petroleum Lad. [1974] A.C. 821, [1974] 2 W.L.R. 689, [1974] ] All E.R. 1126 (P.C.) ${ }^{22}$

One academic author has said the following about the approach the Canadian courts have taken to the meaning of "the best interests of the corporation" in s. 122(1)(a) of the CBCA: "In Canada, the courts have tended to disregard the interests of other stakeholders and to treat the interests of the corporation as coextensive with the interests of shareholders." ${ }^{23}$ It is true that notwithstanding this general statement of the law, VanDuzer also points out that there are some exceptions to it. ${ }^{24}$ However, it is clear that prior to Wise, the weight of Canadian authority on the subject equated "the best interests of the corporation" with "the best interests of the shareholders collectively." But the Supreme Court in Wise holds that this is not in fact the law in this country. Justices Major and Deschamps write as follows:

Insofar as the statutory fiduciary duty is concerned, it is clear that the phrast the "best interests of the corporation" should be read not simply as the "best interests of the shareholders". From an ccononic perspective, the "best interests of the corporation" means the maximization of the value of the corporation: see E.M. Jacobucci, "Directors' Duties in Insolvency: Clarilying What is at Stake" (2003), 39(3) Can. Bus L.J. 398, at pp. 400.1. ${ }^{25}$

Given this assertion by the Court, two questions arise for consideration. First, does the case law cited by the Court actually provide support for this conclusion? Second, if "the best interests of the corporation" does not mean "the best interests of the shareholders collectively," what replaces this standard? Let us consider each of these issues in turn.

The Supreme Court relies on the decision of Berger J. of the British Columbia Supreme Court in Teck Corp. Ltd. v. Millar r. $^{26}$ to justify its holding that the "best interests of the corporation" go beyond the interests of shareholders. In particular, the Court quotes a portion of the judgment from Teck which is reproduced below. Apology is made for the length of the quotation, but as should become apparent, once the portion cited by the Supreme Court is put into the broader context of earlier portions of the judgment in Teck, it is much less susceptible to the interpretation put forward in Wise. The Supreme Court quoted the following excerpt from Teck:

A classical theory that once was unchallengeable must yield to the facts of modern life. In fact, of course, it has. If today the directors of a company were to consider ilie inlerests of its employees no one would argue that in doing so they were not acting bona fide in the interests of the company itself. Similarly, if the directors were to consider the conseguences to the community of any policy that the company intended to pursure, and were deflected in their conmitment to that policy as a result, if could not be said that they had not considered bona fide the interests of the shareholders. 
I appreciate that it would be a breach of their duty for disectors to disregard entirely the interests of a company's shareholders in order to confer a benefit on its employees: Parke v. Daily News Lid., [1962] Ch. 927. But if they observe a decent respect for other interests lying beyond those of the company's shareholders in the strict sense, that will not, in my view, leave directors open to the charge that they have failed in their fiduciary duty to the company. ${ }^{27}$

Immediately prior to the quoted section of the Teck judgment, Berger J. had this to say:

The classical theory is that the directors' duty is to the company. The company's shareholders are the company: Boyd, C., in Martin v. Gibson (1907), 15 O.L.R. 623. and therefore no interests outside those of the shareholders can legitimately be considered by the directors. But even accepting that, what comes within the definition of the interests of the shareholders? By what standards are the shareholders' interests to be measured?

In defining the fiduciary duties of directors, the law ought to take into account the fact that the corporation provides the legal framework for the development of resources and the generation of wealth in the private sector of the Canadian economy: Bull, J.A., in Peso Silver Mines Led. (N.P.L.) v. Cropper (1966), 56 D.L.R. (2d) 117 at pp. 154-5, 54 W.W.R. 329 (B.C.C.A.); affirmed 58 D.L.R. (2d) I. [1966] S.C.R. 673. 56 W.W.R. 641 .

\footnotetext{
... the corporation has become almost the unit of organization of our economic life. Whether for good or ill, the stubbom fact is that in our present system the corporation carries on the bulk of production and transportation, is the chicf employer of both labor and capital, pays a large pan of our taxes, and is an economic institution of such magnitude and importance that there is no present substitute for it except the State itself.
}

Jackson, J., in State Tax Commission v. Aldrich et al. (1942), 316 U.S. 174 at p. $192 .^{28}$

Some academics have already pointed out that the section quoted by the Supreme Court of Canada was technically obiter dicta in Teck. ${ }^{29}$ While this is accurate, the attack made here is much more fundamental. Does Teck actually reject the notion of shareholder primacy, even in obiter? Or does Berger J. simply demand a broader perspective on what is meant by the phrase "the best interests of the shareholders collectively"? In the view of the author, the latter is a more plausible reading of the judgment in Teck.

To justify this conclusion, let us return to the words of Berger J. before the section quoted by the Supreme Court of Canada. In this section, first, he specifically "accepts" the idea that "the best interests of the corporation" means "the company's shareholders." Second, he questions what is meant by the phrase "the best interests of the shareholders of the company." In the author's view, in the section quoted by the Supreme Court of Canada, Berger J. is simply trying to answer the question that he had posed earlier in his judgment. It does not

27 Wise, supra note I at para. 42, quoting Teck, ibid. at 314 [emphasis added].

2" Teck, ibid. at 313-14 [emphasis added].

2v See Wayne D. Gray, "Peoples v. Wise and Dylex: Identifying Stakeholder Interests upon or near Corporate Insolvency - Stasis or Pragmatism?" (2003) 39 Can. Bus. L.J. 242 at 243, note 3; $\tan$ B. Lee, "Peoples Deparment Stores v. Wise and "The Best Interests of the Corporation"” (2005) 41 Can. Bus. L.J. 212 at 214. 
seem as if Berger J. is trying to alter the basic test of fiduciary duty; rather, he is examining the meaning of the test. Justice Berger seems to be demanding a broader perspective when considering "the best interests of the shareholders," but he is not challenging the idea of shareholder primacy.

This interpretation would explain the following sentence from Berger J., as quoted in Wise:

Similarly, if the directors were to consider the consequences to the community of any policy that the company intended to pursue, and were deflected in their commitment to that policy as a result, it could not be said that they had not considered bona fide the imterests of the shareholders. ${ }^{30}$

Note that in discussing fiduciary duty, Berger $J$. is still focused on the interests of the shareholders. Considering the impact of a particular decision on the community is part of acting in the best interests of the shareholders. This would also explain why Berger J. refers to considerations "lying beyond those of the company's shareholders in the strict sense." It is this strict interpretation of the best interests of the shareholders with which Berger J. is expressing disagreement.

Finally, this conclusion is also borne out by the sentence in Teck which immediately followed the portion quoted in the Supreme Court's decision in Wise. There, Berger J. wrote: "In this regard, I cannot accept the view expressed by Professor E.E. Palmer in Siudies in Canadian Company Law, c. 12, 'Directors Power and Duties,' pp. 371-2."32 This is interesting, because the reference to Professor Palmer's work is so specific and limited. It is not necessary to reproduce extensive portions of Professor Palmer's essay. Instead, it is sufficient to point out that the paragraph which straddles pages 371 and 372 - which, according to his citation, appears to be the paragraph with which Berger J. takes issue in Teck - does not directly discuss the holding in Martin v. Gibson, ${ }^{33}$ a case which specifically upholds the notion of shareholder primacy. Marin v. Gibson was dealt with earlier in Professor Palmer's essay, which was not mentioned in Teck. ${ }^{34}$ The relevant paragraph does consider the breadth of directors' duties. It construes these duties as being owed within a very narrow compass. For example, the last sentence of the paragraph reads as follows:

In this vein. [with respect to the scope of directors' duties] the Savoy hotel inspector stated that the imterests of the company's employees and of the nation "would not seem in me so form of a irue legal definition of the interests of the company. "3s"

Therefore, as conceived by Professor Palmer, any consideration of corporate constituencies other than shareholders is inappropriate. As mentioned earlier, it is this strict, narrow approach to the term "best interests of the shareholders" that Berger J. rejects in Teck.

Ibid.

(1907), 15 O.L.R. 623 (H.C.).

" E.E. Palmer, "Directors' Powers and Dulies" in Jacob S. Ziegel. ed.. Siudies in ('anadian ('ompany" Law (Toronto: Butterworths. 1967) vol. 1 at 370 .

is lbid. at 372 [emphasis added, footnotes omitted] 
At least one commentator has argued that "Berger J.'s rejection of shareholder primacy [in Teck] is expressed unambiguously." agree. Rather, at the very least, there is a strong argument that Berger J. was not attacking the notion of shareholder primacy at all, but instead affirming its relevance, as long as the term is construed broadly enough. Therefore, Teck arguably does not support the position of the Supreme Court in Wise.

But, the highest court in the land is entitled to change the law if it feels the change ought to be made. Therefore, simply attacking the law relied on by the Court does not end the enquiry. This leads to the second question posed above: if not the shareholders', then whose interests can be said to represent those of the corporation? This is not definitively answered by the judgment. Instead, the Court holds as follows:

The cast of Re Olympla \& York Enierprises Lid. and Hiram Walker Resources Lid. (1986), 59 O.R. (2d) 254

(Div. Ct.), approved, at p. 271, the decision in Teck. supra. We accept as an accurate statement of law that in determining whether they are acting with a view to the best inserests of the corporation it may be legitimate. given all the circumstances of a given case, for the board of directors to consider, inter alia, the imteresis of shareholders, employees, suppliers, creditors, consumers, governments and the environmen. ${ }^{37}$

The Court continues this theme by holding as follows:

In using their skills for the benefit of the corporation when it is in troubled waters financially, the directors must be careful to attempt to act in its best interests by creating a "better" corporation, and not to favour the interests of any one group of stakeholders. ${ }^{38}$

These two judicial statements are interesting for at least two reasons. First, the Courn does not seem to recognize that taken at face value, these statements may fundamentally alter the scope of directors' duties in Canada. This is a topic to which we will return later in this comment. For the moment, though, the statements are of interest mainly because, in the author's view, they confuse the considerations that are relevant to the "best of the interests of the shareholders," on the one hand, and whether those are the interests that the board is supposed to serve, on the other. The Court is quite correct that suppliers, creditors, consumers, government and the environment are proper considerations to be taken into account in determining the best interests of the corporation, whether the corporation is in financial difficulty or not. Put another way, these are important, but to what end?

Perhaps an example would assist here. If the corporation's goals were devoted to environmental issues, making money is still a good way to bring attention to environmental causes. The larger the corporation, the more money there is to put toward these causes. But if making money starts to get in the way of pursuing environmental goals, the desire to make money must give way. Conversely, if the end desired is money making, it is still acceptable to consider environmental issues, but only to the extent that it fits the ultimate goal - in this 
case, economic success. ${ }^{39}$ The corporation - and thus, the directors who are required to act in its best interests - has had a single lens through which to judge success. Economic success has traditionally been that lens for business corporations.

In 1998, the Government of the United Kingdom decided to undertake a review of its company law. ${ }^{40} \mathrm{~A}$ group of corporate law experts - referred to as the Company Law Review Steering Group (CLRSG) - was asked to head the project. In one of its consultation documents, "1 the CLRSG examined, among other things, the nature and scope of directors' duties in the U.K. According to the CLRSG, there are two broad theories as to the best way to generate wealth for the corporation. The first is referred to as the "enlightened shareholder value" approach. Under this theory, it is claimed that the best way to ensure corporate success is to place shareholders as the primary concern of directors' duties, above other stakeholders. ${ }^{42}$

Under the second theory, known as the pluralist approach, however, the idea of shareholder primacy is, in certain circumstances, to be put to one side in order to serve other constituencies. In other words, in the appropriate circumstances, it is acceptable - and sometimes even necessary - to sacrifice shareholder interests in order to serve other goals. ${ }^{43}$

The difference between these perspectives can sometimes be quite stark. Let us take two examples involving the Ford Motor Company to illustrate this. The first example involves the case of the Ford Pinto. This was a subcompact car which Ford began designing in the late 1960 s. $^{44}$ After the production phase of development had started, the engineers at Ford

The environmental example is based on a discussion in Joel Bakan, The Corporation: The Pathological Pursuit of Profit and Power (Toronto: Viking, 2004), c. 2.

Before continuing. a major difference between the corporate law regimes in most of Canada as compared to the United Kingdom must be recognized. The U.K.'s regime is based on a contractual model of the corporation. In other words, there is a presumed contract between the corporation and each of its shareholders (see s. 14(1) of the Companies ACt 1985 (U.K.) (1985), c. 6, as am.). The CBCA. supra note 2, and other statutes modeled after it are not dependent on contract. but rather on a statutory division of powers model of the corporation. See VanDuzer, supra note 20 at 83-84. Although this difference could potentially allow for certain differences in the scope of directors duties if the shareholders agreed to do so in the memorandum or articles, in general. in the absence of such an agreemem (see The Imperial Mercantile Credil Association (Liquidators of v. Coleman and Kinight (1873), 6 L.R.E. \& I. App. 189 (H.L.)), or a statutory change thereto (see C.BCA, s. 120), directors' duties remain in substance the same in the two jurisdictions. at least to the extent to which we will need to refer to them for the purposes of this discussion.

4 U.K., Company Law Revicw Steering Group, Modern Company Law for a Competitive Economy: The Strategic Framework - A consuliation document from the Company Law Review Steering Group. (London: Department of Trade and Industry, 1999], online: <www.dtigov.uk/cld/comlawfw/> [7he Strategic Framework]. In addition to The Sirategic Framework, the CLRSG also produced Developing the Framework, infra note 61 and Modern Company Lau for a Competitive Liconomy: Completing The Siructure - A consultation document from the Company Law Review Steering Group. (London: Department of Trade and Industry. 2000), online: <www.dti.gov.ul/cld/reviews/comstruc.hinj> [Completing The Structure], and Company Law for a Competime Economy: Fimal Report (London: Department of Trade and Industry. 2001), online: <wnw.dii.gov.uk/cld/final_reporvindex.litm> The Strategic Framework, ibid, at para. 5.1.12.

lbid. at para. 5.1.13.

4 West's California Reporter, "The Pinto Fuel System" in Douglas Birsch \& John H. Fielder. eds.. The Ford Pinto Case - A Study in Applied Ethics. Business, and Technology (Albany: State University of New York Press, 1994) 55 at 55. 
realized that there was a design flaw in their new model." Its gas tank had the unfortunate tendency to rupture when involved in a rear-end collision at approximately 31 miles per hour or above, causing gasoline-fed fires. ${ }^{46}$ Upon learning of the design flaw, executives at Ford undertook a course of action that some would consider unusual. They asked staff to calculate how much it would cost to fix the design flaw. ${ }^{\text {t7 }}$ In addition, members of the staff were asked to calculate the cost of paying out the damages from the anticipated lawsuits resulting from injuries caused by the flaw. ${ }^{48}$ It is alleged that due at least in part to the fact that the latter cost was lower than the former, Ford executives decided not to issue a recall notice to fix the design flaw. ${ }^{\text {t9 }}$

Clearly, in undertaking this calculation, Ford was most worried about the economic bottom line. Even though one could argue that Ford executives did not take account of the long-term impact of their decision - like the damage to the company's reputation when the public learned of the decision - the question remains whether the cost/benefit analysis was appropriate $a$ all..$^{50}$ If one believes in a pluralist approach, one could certainly make an argument that these circumstances would be the time to sacrifice shareholder interests. The argument might run something like this: "A person's life cannot be quantified in dollars and cents. Therefore, when we consider refusing to take action when we know that it is not only possible but in fact likely that people will die when they use the product as intended, the corporation is justified in sacrificing shareholder interests no matter how much money the opposite decision might make for the corporation. We owe it to our customers to make sure that the use of our product is not likely to result in their deaths." The focus of the discussion for the person who subscribes to the pluralist view is on safety and the importance of human life. For the pluralist, these could be sufficiently important to warrant imposing a duty on directors to protect customers, regardless of the impact on shareholders. In other words, once human life is in play, doing a profit-driven calculation is unacceptable.

For those who subscribe to the "enlightened shareholder value" approach, on the other hand. such a calculation is necessary. However, this is not to say that Ford executives got to the right answer in the case of the Pinto. Rather, Ford executives, had they made the opposite decision, arguably would have improved the corporation's reputation, and thereby could have increased sales. As it turned out, the public was outraged by Ford's decision. In fact, one civil jury in California awarded a victim in one Pinto fire US\$125 million in punitive damages,

\section{Dowie, "Pinto Madness" in Birsch \& Fielder, ibid. 15 at 19.} Dowie. ibid. at 17-19.

D.A. Gioia, "Pinto Fires and Personal Ethics: A Script Analysis of Missed Opportunities" in Birsch \& Ficlder, stupra note 44, 97 at 101.

lbid.

lbid. There are certain authors who claim that it is at least possible that Ford did not make its decision based on the cost-benefit analysis. Douglas Birsch. "Product Safety. Cost-Benefit Analysis, and the Ford Pinto Case" in Birsch \& Fielder, supra note 44, 147 at I55 ["Product Safety"]. However. given that Gioia is a former liord employec who acknowledges that the cost-benefit was contained in an internal Ford memorandum (Gioia, supra note 47 at 101 ). it secms virtually beyond debate that a coslbenefit analysis was at least a part of the internal discussion at Ford regarding the appropriate course of action with respect to problems with the Pinto.

In "Product Safety." Birsch argues that ethically, a decision that places a monetary value on human life is unethical - and thus, presumably, unacceptable. See Birsch, ibid. at 161 . In the view of the author. this would seem to suggest a lavouring of the pluralist approach. as defined (Note: Both Birsch and Fielder, the editurs of the volume, are philosophical experts, and not legal ones.) 


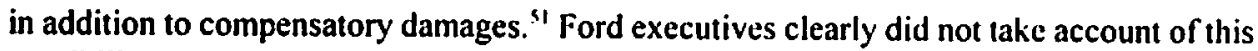
possibility and its potential impact on sales - nor the possibility of a highly publicized criminal trial for homicide in Indiana, ${ }^{52}$ in which Ford was eventually found not guilty - in their decision making. Therefore, even those who subscribe to the "enlightened shareholder value" approach would likely agree that Ford executives came to the wrong result here. However, to say that the executives came to the wrong result does not preclude the argument that the calculation should be undertaken when done properly.

Nonetheless, even the most ardent capitalist might have trouble justifying the morality of allowing people to die in the name of profit. A second example may therefore be helpful to further illuminate this discussion. In 1916, Ford Motor Co., then headed by Henry Ford, was one of the most profitable companies in America. Mr. Ford, the company's dominant shareholder who controlled the board of directors at the time, announced that the company would, for an indefinite period, no longer be issuing special dividends to shareholders. ${ }^{33}$ The Dodge brothers were shareholders in Ford Motor $\mathrm{Co}^{54}$ The brothers challenged the authority of the Ford Motor Co. board to make this decision, arguing that it was not in the best interests of the corporation. The Supreme Court of Michigan agreed. The opinion of the Court focused on the admission by Mr. Ford that his decision was not motivated by profit. Instead, the Court held that Mr. Ford's testimony

creates the impression, also, that lie thinks the liord Motor Company has made too much money, has had loo large profits, and that although large profits might be still carned, a sharing of them with the public, by reducing the price of the output of the company, ought to be undertaken. We have no doubt that certain sentiments, philanthropic and altruistic, creditable to Mr. Ford, had large influence in determining the pelicy to be pursued by the Ford Motor Company - the policy which has been herein referred to."

In other words, profit making is the end goal of a business corporation. The payment of dividends is an expression of profitability. ${ }^{56}$ The dividends go to the shareholders. Clearly, the decision in Dodge was impliedly premised on the enlightened shareholder value approach. After all, the Court made it clear that Mr. Ford did have a laudable goal in mind in undertaking the decision. His goal was philanthropic and aimed at improving the community. ${ }^{57}$ In spite of this laudable goal, the Court was willing to force Mr. Ford to retract his philanthropic policy, as it interfered with the potential for the earning of profit, rather than enhancing it.

On the pluralist view, however, the analysis of the Court could have been the opposite. If the needs of the community were pressing, it is possible that the decision of the board of the

This award was reduced by the trial judge to $\$ 3.5$ million. The trial judge's reduction of damages was later affirmed by the California Court of Appeal. See Grimshan $v$. Ford Motor Co. 119 Cal ipr id 757 (1981). See lee Patrick Sirubel, Reckless Honicide?. Ford's Pinto Trial (South Bend. Ind. And Books, 1980) Dodge v. Ford Motor Co. 170 N.W. 668 (1919) (Mich. Sup. (1.) |Dodgel at 683

Ibid at 609

Ibid. at 683-84. Ostrander J. for the majority of the Court.

Dividends can only be paid out if after the payment: (a) the corporation will be able to pay its delts generally as they come duc; and (b) assets are greater than both liabilities and the value of shares. Sic $C B C A$, supra note 2, 5. 42.

Dodge. supra note 53 at 684 
Ford Motor Co., to sacrifice profit in favour of the good of the community, as exemplified by the testimony of Mr. Ford, might have been acceptable. This would be justified on the basis that the interests of the community should trump the interests of shareholders in these circumstances. These two examples show the potential differences between the two approaches.

Unfortunately, the Supreme Court of Canada apparently does not wish to explicitly resolve in Wise which one of these approaches is to govern in Canadian corporate law. Instead, the Court says that the directors must act to make the corporation a "better corporation." ${ }^{\text {.88 }}$ Yet, the desire to make a "better" corporation does not, in and of itself, resolve which perspective finds favour with the Court. As the CLRSG explains:

[T] he lnw must indicate whether shareholder interests are to be regarded as overriding, or some other kind of balance should be struck. This requires a choice, we believe, between the enlighened sharcholder value and pluralist approaches. An appeal to the "interests of the company" will not resolve the issue, unless it is first decided whether "the company" is to be equated with its shareholders alone (enlightened shareholder value), or the shareholders plus other participants (pluralism). ${ }^{39}$

For ease of reference, two portions of the Supreme Court's judgment set out earlier are repeated immediately below:

Insofar as the statutory fiduciary duty is concerned, it is clear that the phrasc the "best interests of the corporation" should be read not simply as the "best interesis of the sharelonlders.".. We accept as an accurate statement of law that in determining whether they are acting with a view to the best interests of the corporation it may be legitimate, given all the circumstances of a given case, for the board of directors to consider, inter alic. the interests of shareholders, employees, suppliers, creditors. consumers, governments and the environment. 60

First, the Court has, by the first sentence reproduced, explicitly undermined the traditional view of what "the best interests of the corporation" means. The Court seems to think that the "enlightened shareholder value" approach has too narrow a focus. The Court does not seem to appreciate that, interpreted properly, the "enlightened shareholder value" approach does not prohibit valuing these other factors. At one level, this is the "enlightened" part of the "enlightened shareholder value" approach. As the CLRSG puts it, in assessing the responses from its consultation process:

A very substantial majority of responses (in number and in weight) favoured retaining the basic rule that directors should operate companies for the benefit of members (i.e. normally sliareholders). However there was also very strong support for the view that this needed to be framed in an "inclusive" way. There was concern that in many companies there was not sufficient appreciation (either by directors or by shareholders) of the importance of running busincsses with a strategic, balanced view of the implications of decisions over time, with proper emphasis on the long term. Due recognition wis also needed of the importance in modern 
business of fostering effective relationships over time, with employees, customers and suppliers, and in the community more widely.

[There is a]n obligation on directors to achieve the success of the company for the benefit of shareholders by taking proper account of all the relevant considerations for that purpose. These include a proper balanced view of the short and long term; the need to sustain effective ongoing relationships with employees. customers. suppliers and others; and the need to maintain the company's business reputation and to consider the impact of its operations on the community and the environment. ${ }^{61}$

Therefore, adopting the "enlightened shareholder value" approach does not suggest that there should be no consideration of the impact of decisions on corporate constituencies other than shareholders. Rather, these other constituencies are relevant, but once service to these other constituencies undermines shareholder value in the long term, it is unacceptable. Put another way, even though one wants to achieve welfare maximization for all constituencies, ${ }^{62}$ the best way to do this is through promoting the interests of shareholders, but only in a way that recognizes the importance of these other constituencies.

This has also been recognized in Canada. VanDuzer, ${ }^{01}$ after setting out the fact that Canadian courts have equated "the best interests of the corporation" with shareholder interests, to the exclusion of other stakeholder interests, writes as follows:

No corporation will maximize share value if it completely ignores the interests of its cmployees, customers. creditors and other stakeholders, but management is not permitted to favour the interests of other stakeholders at the expense of share value. ${ }^{\text {.4 }}$

Therefore, the Court's reasoning that since the directors should be able to consider other stakeholder interests meant that "the phrase the 'best interests of the corporation' should be read not simply as the "best interests of the shareholders"' does not necessarily follow. Even if shareholder interests are paramount, ignorance of other constituencies is neither counseled nor a prudent course for directors who wish to serve the corporation well, as VanDuzer indicates. Instead, in the "enlightened shareholder value" approach, all the relevant constituencies (including employees, suppliers, creditors, customers, the environment and even the community at large) must be considered in order to serve shareholder interests adequately.

Earlier, it was mentioned that the Court is changing the law and perhaps did not realize that it was doing so. As should be obvious from VanDuzer, until Wise was decided, the majority of Canadian decisions with respect to directors' fiduciary duty have implicitly adopted the "enlightened shareholder value" approach, as set out by the CLRSG. Yet the

U.K., Company Law Revicw Steering Group. Modern Compan) Law for a ('omperthive ficonomy. Developing the Framework - A consullation document from the Company Lant Review Stecrung Group. (London: Department of Trade and Industry. 2000). online: <www.dti.gov.uk/cld/claw 2_3.pdis at paras. 2.11, 2.19 [Developing the Framework] 
decision in Wise throws the idea of shareholder primacy into serious question, if not jettisoning it entirely. But the Court is not clear about which approach it is taking to replace the traditional view. Is the Court holding that unlike our friends "across the pond," we should adopt the pluralist approach, as opposed to its "enlightened shareholder value" counterpart?"5.5 Since the Court explicitly rejects the notion of the primacy of shareholder interests - the lynchpin of the "enlightened shareholder value" approach - the answer would appear to be "yes."

However, this would be a marked change in the law to this point. Yet the entire tenor of the judgment in Wise seems to treat the Court's exposition on this area of law as little more than a restatement of principles with which anyone conversant in the law of corporations should already be familiar, and which should raise little in the way of controversy. The title of this comment - that the Court "restated" directors' fiduciary duty — reflects the Court's goal. However, if this was in fact the Court's hope, the author doubts that the Court achieved this particular goal. To the author, this seems to suggest that Major and Deschamps JJ. may have been trying to "tweak" the law of directors' duties, but they may have unintentionally gotten more than they bargained for.

\section{B. Process Concerns}

The previous subsection dealt with the substantive reasoning of the Court. This subsection, on the other hand, deals with the relationship between the courts and the legislative and executive branches of government in determining the scope of directors' duties. In particular, a brief examination of the U.K.'s company law review process with respect to directors' duties will be contrasted with the Canadian experience - that is, the judgment in Wise.

The contrast, in terms of process for reviewing the scope of directors' duties, between the two jurisdictions is quite telling. As mentioned earlier, when the U.K. sought to undertake a review of the scope of directors' duties, it was a government-sponsored initiative. Furthermore, the initiative was consultative, ${ }^{60}$ and thus, transparent. Finally, the process was democratic, in that one of the recommendations of the CLRSG is that the Parliament of the U.K. should adopt a statutory statement of directors' duties, ${ }^{67}$ similar to 5.122 of the $C B C A$. In other words, the U.K. process left the final decision with respect to whether to change the law regarding directors' duties in the hands of both elected officials and the bureaucrats whose role it is to support legislative progress, and collectively, to determine and further the public interest.

Let us compare this to the Court's decision. The review of directors' duties was not requested by either the executive or legislative branches of government. This is so, even though both branches of government retain a right to refer certain matters to the Court. ${ }^{68}$ In other words, had the government felt that it needed the Court's advice regarding whether to change the law regarding the duties of directors, it had - and continues to have $-\mathrm{a}$

\footnotetext{
We will relurn to other questions arising out of the application of the pluralist approach in Part IV(C)
"Uncertainty Concerns," infra.

... See, for example, Developing the Framework, supra note 61 at paras. 2.7 through 2. 18

Ibid. at para. 2.19.

t.k Sec. for example the Supreme Court Act, R.S.C. 1985, c. S-26, ss. 53 (I)(b). 54.
} 
mechanism in place to do so. The government did not exercise this right. In spite of what happened in the cases of Enron ${ }^{69}$ and $W_{\text {orldCom }}{ }^{70}$ as well as a spate of other corporategovernance-related scandals, the government of Canada has not chosen to re-examine the role of directors' duties and how those duties are exercised. ${ }^{71}$ Of course, supporters of the decision would undoubtedly point out that the issue was raised in the context of a case which was legitimately before the Court. The supporters of the decision would argue that the Court cannot shirk its responsibility to resolve its cases simply because the Court might feel that the issue is better left to Parliament to resolve.

There are four responses to this argument. First, note should be made of the following words written by Pelletier J.A., speaking for the Quebec Court of Appeal in Wise:

I believe that, in advocating the extension of that theory [of protecting creditors through the application of fiduciary duty to creditors when the corporation is in the vicinity of insolvency] to Canadian law, the trial judge encroached on the legislator's field of intervention in that the legislator establishes a general regime of director liability of benefit to third parties aggrieved by the management acts of directors. I am not disposed to follow that approach.

In 1978, the Canadian lanv was completely revised without the legislators/'] explicit acceptance of the principle of the general liability of direciors so third parties. I said apparently because such a shift away from traditional thought would, in my opinion, require an explicit, clear provision. Nothing of the kind is found in that Act of Parliament. ${ }^{72}$

The Court of Appeal uses legislative inaction by Parliament on the issue of shifting fiduciary duty to creditors as one reason not to do so by judicial fiat. Changes to the statutory law of fiduciary duty under the $C B C A$, if they are to be made at all, according to the Quebec Court of Appeal, should be made by Parliament, not the courts. The same reasoning applies equally to the change offered by the Supreme Court of Canada in Wise. After all, the Court of Appeal rejects the change to the law made by the Superior Court of Quebec. Yet, even in dismissing the appeal from the decision of the Court of Appeal, the Supreme Court of Canada does what the Court of Appeal said should not have been done by the trial judge - that is, a judicial change to the law of statutory fiduciary duty under the $C B C A$.

Joseph Kahn with Jonathan D. Glater, "Enron Auditor Raises Specter of Crime" The New York Times (13 December 2001) Cl.

7. Simon Romero \& Alex Berenson, "WorldCom Says It Hid Expenses, Inflating Cash Flow \$3.8 Billion" The New York Times (26 June 2002) Al. Interestingly, a notorious Canadian corporate scandal was at least one impetus for statutory reform in another area of corporate law. Corporate criminal liability has been significantly altered by Parliamentary initiative. This was a response to the Nova Scotia Westray mining tragedy. See An Act 10 Amend the Criminal Code (criminal liability of organizations). S.C. 2003, c. 21. However, this statute generally deals with the liability of organizations (corporations, parnerships, etc.) and generally (subject only to a couple of exceptions - see s. 217.1 of the Criminal Code. R.S.C. 1985, c. C-46, as am.) leaves directors entirely outside its ambit. Also, the $C B C A$, supra note 2 , underwent a fairly substantial revision in 2001. See An Act to amend the Canada Business Corporations Act and Canadu Cooperatives ACt and to amend other Acts in consequence, S.C. 2001, c. 14. The point of this discussion is that if Parliament had wished to alter the scope of directors' duties as part of a thoroughgoing review of corporate law, it has had ample opportunity to do so. This makes the Court's decision to alter directors' duties through its judgment in Wise all the more intriguing. Wise, C.A., supra note 24 at paras. 93-94 [emphasis added]. 
Second, since the case did not involve constitutional questions, none of the federal and provincial Attorneys-General was represented at the hearing. Thus, this was solely a dispute about money. The issue with respect to fiduciary duty in $W$ ise could have been simply stated as follows: Can the creditors of a corporation rely on the statutory statement of fiduciary duty to force the directors to protect the interests of creditors? If this is so, then the creditors can recover some money lost in the bankruptcy of the corporation from the directors. If not, then creditors are restricted to rights in bankruptcy. That part of the case is about money.

But the potential effect on business of a change to our understanding of the nature of directors' fiduciary obligations is much more polycentric and policy-oriented, with wideranging implications for commercial practice for both law and business alike. These important public policy concerns cannot be forgotten simply because the dispute (on its surface, at least) appears only to concern private parties. Seeking the views of the AttorneysGeneral should help to convey the important message that changes to the law of corporations in an area as fundamental as directors' fiduciary duty involve a public interest which may extend far beyond the immediate needs of the parties to the dispute.

An example may assist here. For the purposes of this example, assume - as is not in fact the case - that the private parties involved in the case agreed that the fiduciary duty of directors should shift to the creditors in certain circumstances. Assume, furthermore, that the disagreement between the parties related to when - but not if - this should occur, and whether the facts of the case met the relevant criteria for shifting the fiduciary duty. One of the public policy dimensions of corporate law is the desire to facilitate risk-taking and investment in businesses by members of the public, and not to unduly restrict this freedom. ${ }^{73}$ Therefore, even if the parties were agreed on a particular point of corporate law, certain aspects of corporate law serve fundamental policy concerns. Changing the law with respect to directors' fiduciary duty may impact these policy goals, and therefore, this may be sufficiently important to warrant protecting the public interest before so doing. A public process where the public interest is explicitly to be considered puts these policy issues at its forefront. A court case between private parties may not do this nearly as well. Exactly how the Court chooses to protect and address these public policy issues need not be resolved here. The only point to be made here with respect to these issues is that the Court ought to make sure that it explicitly does so.

Third, on a related point, a court's opinion is not consultative with the business world, nor should it be. But, that same court should recognize the fact that the involvement of the business community is critically important in any fundamental change to business law. This can be seen in the recent corporate governance reform process in Canada, ${ }^{74}$ and the public

In fact, the majority of the Supreme Court of Canada has already held that the incorporation statute in Saskatchewan (the Business Corporations ACl, R.S.S. 1978. c. B-10, which is modeled on, and for our purposes, the functional cquivalent of the $C B C A$ ) is in essence facilitulive of business. See McClurg v. Canada. [1990] 3 S.C.R. 1020 at para. 34. Dickson C.J.C. See also VanDuzer. supra note 20 at $93-$
98. c. 3E "Functions of Corporate Law."

See Toronto Stock Exchange Committec on Corporate Governance in Cinada, Where Were the Directors? The Report of the Toromo Stock Exchange Committee on Corporate Governance in Canada (Toronto: Toronto Stock Exchange, 1994) (sponsored by the Toronto Stock Exchange and the Institute of Corporate Directors). See also Joint Cominittee on Corporate Governance in Canada, Beyond Compliance: Building a Governance Culture - Final Report of the Joint Committee on 
consultation process undertaken by securities administrators before making or changing any rule put forward under rule-making authority. ${ }^{75}$ In the author's view, these consultation processes demonstrate that legislators and regulatory bodies prefer to fully understand the potential impact of decision making for those "on the ground" in the business world. In other words, regulators and others have recognized the value of building consensus with business leaders before changing the legal landscape in a way that affects business.

Fourth, by the Supreme Court in Wise appropriating to itself the ability to undermine the notion of shareholder primacy, some may claim that the decision is undemocratic because the law was changed by seven unelected judges, as opposed to being altered by the elected legislatures. However, since the case did not involve a constitutional principle, the legislature retains the power to clarify the law through statutory amendment. So, all is not lost on the democratic front.

Earlier, mention was made of the concept of transparency. To call this judgment rather ambiguous would not be unwarranted, and has been done publicly by at least one corporate law expert. ${ }^{76}$ The Court is clear that the traditional definition of what is meant by "the best interests of the corporation" no longer applies. As mentioned earlier, the Court does not clarify what is to take its place. We will return to this in subsection IV(C) below, but for now, it is sufficient to say the end result of the Court's judgment is not clear on this point.

In conclusion with respect to this subsection, changing the law of directors' statutory fiduciary duty through judicial decision in a case between private parties may not be the best possible outcome in terms of process. The Court needed to ensure that the important public policy aspects of corporate law are reflected in the decision, and to ensure that the public interest is thus protected. A more transparent. consultative process, such as that undertaken by regulators in other areas of business law, might have been more appropriate.

\section{UNCERTAINTY CONCERNS}

The trustee in this case was asking that directors' fiduciary duty shift to protect creditors when the corporation at issue is "in the vicinity of insolvency." In other words, the intent of the trustee seems to have been to leave intact the general rule of shareholder primacy. This general rule would change only when there is little or no residual value reasonably expected to go to shareholders in light of the financial trouble in which the corporation finds itself. The change, therefore, was to move the obligations of directors in determining the "best interests of the corporation" from consideration of the interests of one group (the shareholders collectively) to another (the creditors) in a particular set of circumstances (when the corporation is in the vicinity of insolvency). Even if these circumstances could not be exhaustively defined by the Canadian courts in advance, they have been sufficiently

Corporate Governance (Toronto: Torontu Stock Exchange, 2001) (spunsored by the Toronto Stock Exchange, the Canadian Institute of Chartered Accountants and the Canadian Venture Exchange). For a description of the consultation process of the Ontario Securities Commission in proposing rules, see "Rule making in Ontario," online: <isww.osc.gov.on.ca/Regulation/Rulemaking/rrn_backgrounder. jsp>.

2. See Anita Anand, "Supreme Ambiguity" The National Post (18 November 2004) FP15. 
understood for use by courts in the U.K., ${ }^{77}$ from which Canada has derived much of our early jurisprudence with respect to directors' fiduciary duty. ${ }^{78}$

The Court in Wise rejects this argument. ${ }^{79}$ At least part of this rejection was based on the ambiguity in the phrase "in the vicinity of insolvency." 80 The author does not wish to take issue with this rejection in this comment. Certainty in the law is a good thing. As the author has argued in another article, ${ }^{81}$ this is particularly true in the case of business law issues, where the very appearance of uncertainty can have a negative impact on the economy. So, at the level of theory at least, one might think that the author would support the choice of the Court in favour of certainty. But the rejection of the argument of the trustee does not end the issue. In fact, this simply begs the question: Is the change to the law offered by the Court in $W$ ise any better, in terms of certainty, than the argument put forward by the trustee?

The Court, rather than expanding the obligations of directors to a particular group in limited circumstances, as argued by the trustee, says that directors are required to protect a multitude of constituencies as part of serving "the corporation." The Court could have tried to define the circumstances in which the interests of other constituencies would take precedence over those of shareholders, who are clearly an important part of any corporation. ${ }^{82}$ Regrettably, however, the Court provides no meaningful guidance to allow directors to structure their decision making. So, uncertainty is to be avoided, which the Court arguably does by rejecting the trustee's argument. But different uncertainties are created when the Court accomplishes this by undermining the idea of shareholder primacy without guidance as to how this altered framework is to operate. This, in the view of the author, is even less desirable.

But certainty is never absolute. Uncertainty in the law is sometimes both necessary and advisable. For example, it is difficult to spell out in advance what will be required to meet the "reasonable person" standard in negligence. ${ }^{83}$ Yet it is both necessary and advisable to have an elastic concept so as to allow the law of negligence to achieve its goals. Perhaps it is equally necessary and advisable to build similar elasticity into the law of directors' duties.

See for example. Jacob S. Ziegel. “Creditors As Corporate Stakcholders: The Quiet Revolution - An Anglo-Canadian Perspective" (1993) 43 U.T.L.J. 511 at $511-12$, as cited with approval by Greenberg J. of the Quebec Superior Court in the trial judgment in Wise (1998), 23 C.B.R. (4th) 200 at para. 190. See also, Re: Horsiey \& Weight Lid. [ 1982] 3 All E.R. 1045 (C.A.) at 1055. Cumming-Bruce, L.J. and at 1056, Templeman, L.J. (as he then was), although both comments were technically obiter dicta. Lord Justice Buckley casts some degree of doubt on these statements in the context of this case, at 1055. See also Winkworth v. Edward Baron Development Co. Lid. et al., [1986] I W.L.R. 1512 (H.L.), where Lord Templeman, for the unanimous House of Lords, confirmed that equity places cerlain equilable duties on directors for the benefit of creditors (at 1516). See, for example, Aberdeen, supra note 18.

Wise, supra note I at para. 53.

Jbid. at para. 46.

See Darcy L. MacPherson. "The B.C. Tobacco Legistation Litigation - $\wedge$ Comment on the Papers of Prolessors Edinger and Elliot" (2005) 41 Can. Bus. L.J. 386. In the otluer article, lhe author suggests that the decision in British Columbia v. Imperial Tobacco Canada Lod (2004). 239 D.L.R. (4th) 412 (B.C.C.A.) created an unacceptable degree of uncertainty for business. Even though those comments applied in a different context (in that case, the determination as $t($ ) the constitutionality of provincial legislation), they are equally apposite here.

*: Nise, supra note 1 at para. 44.

" Philip H. Osborne, The Law of Torts (Toronto: Irwin Law, 2003) at 26-28. 
Therefore, even assuming that the rejection of the trustee's argument was correct, given the end result, the next question to be asked is whether it was both necessary and advisable to change the law to the degree that the Court did here. The author would answer this question with a resounding "no." Let us consider each of these elements - necessary and advisable - in turn.

In terms of necessity, the question is a simple one: Could the Court have gotten to the desired result without changing the law as it did in Wise? If so, then the necessity criterion is not met. In the author's view, such is the case here. After all, the narrow question asked of the Court was essentially the following: Does the statutory fiduciary duty of directors ever extend to protect the interests of creditors as an end unto themselves? Clearly, the judgment of the Court answers that question in the negative. ${ }^{84}$ If the Court leaves its judgment with respect to fiduciary duty at that point, it achieves the same result - that is, creditors cannot allege a breach of a director's fiduciary duty owed to them - without changing the law drastically, or at all. The Wise brothers still would not have been liable for breach of fiduciary duty. Broader issues around the meaning of "the best interests of the corporation" could have been left to another day. Instead, the Court chooses to extend its reasoning and to undermine the notion of shareholder primacy in the process.

Even if the change to the law made by the Court is not, strictly speaking, necessary, is it advisable? There is much to recommend a more inclusive, pluralist approach to fiduciary duty. Some critics say that the current construct of the corporation encourages the corporation to foist as many cosis as possible on to other people, a process referred to as "externalization." "L5 Laws and other forms of regulation can be used to force corporations and others to internalize, that is, pay for, certain costs that might otherwise be externalized on to others. ${ }^{86}$ Nothing in this comment should be taken as suggesting that the pluralist approach is without significant merit.

However, even with all the potential positives of a change from an "enlightened shareholder value" approach to a "pluralist" approach, the Court's decision in Wise does have another obstacle to overcome. As mentioned earlier, the Court provided little information to directors to guide their decision making going forward. Even if absolute certainty in advance is not possible, guiding principles become all the more important so that corporate directors can adjust their decision-making process to take account of this change in the law and adapt to the pluralist mentality. The obstacle is that the Supreme Court did not give corporate directors those principles. Those principles are necessary guideposts for the future. This means that directors will have to wait for future case law to give them this guidance. Until then, corporate directors are left to wonder about what actions might lead to a successful lawsuit for breach of fiduciary duty. With due respect to the Supreme Court, surely this vacuum cannot be advisable from a policy perspective.

W'ise, supra note 1 at para. $\$ 3$

" Bakan. stupra note 39 at c. 3

w. Ibid. In fact. Bakan argues throughout the relevant chapter that de-regulation is one of the primary tools to allow for extemalization. Therefore, the author calls for a re-conceptualization of the relationship between govemment and the institution of the corporation (see Bakan, c. 6) to lessen some of the negative claaracteristics of the corporation, including its tendency toward externalization. 


\title{
V. MALA FIDES AND FidUCIARY DUTY
}

The final point to be made about the judgment of the Supreme Court in Wise relates to the importance of mala fides in finding a breach of fiduciary duty. In this regard, the Supreme Court holds as follows:

In our opinion, the trial judge's determination that there was no fraud or dishonesty in the Wise brothers' antempts to solve the mounting inventory problems of Peoples and Wise stands in the way of a finding that they breached their fiduciary duty. Greenberg J. [the trial judge] stated. at para. 180:

\begin{abstract}
We hasten to add that in the present case. the Wise Brothers derived no direct personal benefil from the new domestic inventory procurement policy, albeit that, as the controlling shareholders of Wise Stores, there was an indirect benefit to them. Moreover, as was conceded by the other parties herein, in deciding to implement the new domestic inventory procurement policy, there was no dishonesty or fraud on their part. ${ }^{87}$
\end{abstract}

The Supreme Court seems to be suggesting that the absence of mala fides or self-interest on the part of directors can save the directors from a breach of fiduciary duty. On the facts of the case, the lack of mala fides clearly weighed heavily in the decisions of both the Quebec Court of Appeal ${ }^{88}$ and the Supreme Court of Canada. ${ }^{89}$ The author does not wish to challenge this holding on the facts of Wise. However, this is a judgment of the Supreme Court of Canada that will undoubtedly have great value as a precedent going forward. Thus, in the author's view, it is important to ensure that the portion of the judgment quoted above is factspecific and does not represent a general statement of the law.

Current case law provides examples where the courts have acknowledged that, even if there is neither personal benefit to, nor fraud on the part of, the directors, there can still be a breach of fiduciary duty. For example, in Re: Sports Villas Resort (sub. nom. Pardy v. Dobbin), ${ }^{90}$ the issue was competition with the corporation. There was an attempt to remove a director of one corporation who was also a director of a second corporation. It was argued that the two corporations might compete with each other. The Newfoundland Court of Appeal, citing the Supreme Court of Canada's decision in Canadian Aero Limited $v$. $O$ 'Malley and Zrzycki, ${ }^{91}$ held as follows:

In the general terms employed by Camadian Aero, this hoids dircetors to the obligations of acting towards companics on whose boards they sit with "loyalty, good faith and avoidance of conflict of duty and selfinterest." This involves a dun not just to avoid actual conflict of duty and interest, but also potemtial confict. ${ }^{92}$

The Newfoundland Court of Appeal held that there was neither actual nor potential conflict - that is, competition - on the facts of the case. However, this case confirms that, even if

Wise, supra note I at para. 40.

See Wise, C.A., supra note 24 at para. 61.

Wise, supra note I at para. 40.

(2000), 185 NAd. \& P.E.I.R. 281,2000 NFCA 11 [Parcly].

[1974] S.C.R. 592, which is alsu cited with approval by the Supreme Court of Canada in Wise, supra nole $I$ at para. 38 [emphasis added].

"2 Pardy, supra nole 90 at para. 55 [emphasis added] 
the good faith of the directors is actually proven, and there is no allegation of self-dealing, before Wise it was clear that "potential conflict between interest and duty" would be sufficient to prove a breach of fiduciary duty. Once again, perhaps an example will assist here. Assume that Person $\mathrm{X}$ is a director of one corporation. Person $\mathrm{X}$ is then asked to serve on the board of a second corporation. Both corporations are pursuing the same opportunity. Person $\mathrm{X}$ is acting in good faith with respect to both corporations. Person $\mathrm{X}$ owns no shares in either corporation, and will receive no benefit from any part of the opportunity, regardless of which corporation is successful in obtaining it. In such a case, though, Person $\mathrm{X}$ will commit a breach of fiduciary duty if he or she does not avoid the actual or potential conflict between the obligations owed to each of the corporations. So, in conclusion, as a general rule, it is possible to have a breach of fiduciary duty even without mala fides and without there being direct benefit to the directors.

\section{WHAT IS NEXT?}

The conclusions to be drawn from the analysis have been laid out earlier (in Part III). There is no need to repeat them. However, it is interesting to speculate about how the decision in Wise will impact the exercise of directors' duties going forward. Will the courts generally continue to favour shareholder interests in all but the rarest of circumstances? Or will the courts decide that shareholders will be subordinated more regularly and easily to the needs of other corporate stakeholders? Will the judgment in Wise affect the way that directors will conduct themselves in meetings? Will the lower courts provide the guidance that directors will need to regulate their conduct vis-à-vis the corporation? If so, how long will this take? Will the uncertainty in the interim make directors more conservative in their decision making? If so, how will this conservative attitude manifest itself? All of these questions will eventually be answered. At this point, though, the Supreme Court's judgment in Wise brings up more questions than it answers. For now, we can only hope that the answers will come sooner, rather than later. But, only time will tell. 